\title{
Journal of Bacteriology and

\section{Diagnostic Aspects and Novel Approach for Treatment of Antibiotic-Resistant Bacteria Isolated from Diarrheal Calves using Silver, Gold and Copper Nanoparticles}

\author{
Ayman El Behiry ${ }^{1,2^{*}}$ \\ ${ }^{1}$ Department of Bacteriology, Mycology and Immunology, Faculty of Veterinary Medicine, Sadat City University, Egypt \\ ${ }^{2}$ Department of Public Health, Microbiology, College of Public Health, Qassim University, Kingdom of Saudi Arabia (KSA) \\ "Corresponding author: El Behiry A, Department of Bacteriology, Mycology and Immunology, Faculty of Veterinary Medicine, Sadat City University, Egypt, Tel: \\ 00966532207969; E-mail: aymanella2007@yahoo.com
}

Received date: July 12, 2014; Accepted date: July 31 2014; Published date: August 2, 2014

Copyright: @ 2014 El Behiry A. This is an open-access article distributed under the terms of the Creative Commons Attribution License, which permits unrestricted use, distribution, and reproduction in any medium, provided the original author and source are credited.

\begin{abstract}
This study was performed to identify various bacteria from feces of calves suffering from diarrhea, and to determine in vitro antimicrobial activity of silver, gold and copper nanoparticles against the antibiotic-resistant bacteria isolated from fecal samples. Fecal samples were collected from 153 diarrheic calves and primarily tested for the presence of Escherichia coli, Salmonella spp. and Staphylococcus aureus using bacteriological examination, biochemical reactions and polymerase chain reaction. The minimum inhibitory concentrations of silver, gold and copper nanoparticles against identified bacterial isolates were determined by a broth dilution method. 84 bacterial isolates from the 153 fecal samples were identified using bacteriological, biochemical and genotypical methods. Escherichia coli was considered the most frequent bacterium isolated numbering $31(36.90 \%)$ followed by Salmonella sp. as the second most prevalent $16(19.04 \%)$. Further isolates such as Staphylococcus aureus 10 $(11.90 \%)$ were isolated and identified. The MIC values of silver, gold and copper nanoparticles with a size of 10 nanometers $(\mathrm{nm})$ against the three types of bacteria were ranged from 0.625 to $10 \mu \mathrm{g} / \mathrm{ml}, 2.5$ to $20 \mu \mathrm{g} / \mathrm{ml}$ and 2.5 to $20 \mu \mathrm{g} / \mathrm{ml}$, respectively. While these values with a size of $20 \mathrm{~nm}$ were 0.312 to $2.5 \mu \mathrm{g} / \mathrm{ml}, 1.25$ to $10 \mu \mathrm{g} / \mathrm{ml}$ and 2.5 to $10 \mu \mathrm{g} / \mathrm{ml}$, respectively. Additionally, the mean time of the antimicrobial action of silver, gold and copper nanoparticles at concentration $10 \mathrm{~nm}$ against all isolates was $5 \mathrm{~min}, 30 \mathrm{~min}$ and $15 \mathrm{~min}$, respectively. Using of these nanoparticles in a concentration of $20 \mathrm{~nm}$, the mean time was 1,15 and $5 \mathrm{~min}$, respectively. These in vitro results clearly indicate that the silver, gold and copper nanoparticles might have a superior activity and rapid onset of action against the Gram negative bacteria E. coli and Salmonella spp. and the Gram positive bacteria Staphylococcus aureus with diarrheal origin.
\end{abstract}

Keywords: Calf diarrhea; Antibiotic-resistant bacteria; Nanoparticles; Treatment

\section{Introduction}

Calf diarrhea caused by bacterial infection has a bad effect on the dairy industry all over the world when calves are reared intensively. It involves significant economic loss for labor and capital, calf mortality, loss in calf value and veterinary costs $[1,2]$. The pre-weaning mortality of dairy calves was estimated by the National Animal Health Monitoring System in the United States at $10.8 \%$ with diarrhea responsible for more than half of those deaths $[1,3]$. Diarrhea caused by a variety of bacteria has been recognized as one of the most public clinical problems for calves worldwide. Among these bacteria Eschirechia coli (E. coli) as "white scour", Salmonella typhyimurium (S. typhimurium), Clostridium perfringens (C. Perfringens) and Staphylococcus aureus (St. aureus) are believed to be the major microbial causes of diarrhea in calves [4-6].

Antimicrobial agents are considered popular to fight diarrhea in calves. Nevertheless, their wide spectrum of activity, the emergence of microbial tolerance of different antimicrobial agents has become a well-known phenomenon, which represents a major concern [7]. Resistance to antimicrobial agents was frequently occurred in Salmonella species and E. coli particularly in pre-weaned dairy calves
[8]. The frequent resistance of various microorganisms to the majority of antimicrobial agents is catching the attention of a great deal of awareness. The World Organization for Animal Health (OIE), Food and Agriculture Organization of the United Nations (FAO), and World Health Organization (WHO) have all commented on the severe threat formed by antibiotics-resistant bacteria in livestock and human health [9]. The frequent use of antibacterial agents has created the selective pressure to enhance the rising rates in antibiotic tolerance to different types of bacteria $[10,11]$. Consequently, due to the truth that microorganisms developed resistance against several types of antimicrobial agents, communicable diseases persist to be one of the most important public health problems in different countries. In addition, the disadvantages of frequently used antimicrobial agents are not only the development of multiple drug resistance, but also adverse side effects [12]. As a result of antimicrobial resistance in the diarrhea of pre-weaned calves, there is an increasing attention in using alternative antimicrobial agent [1,7]. Consequently, there is an urgent need to find out an innovative approach and recognize new antimicrobial agents from natural and inorganic substances to develop the next generation of antimicrobial agents to control different microbial infections [7]. Therefore, Nanoparticles (NPs) are considered one of the most important new policies for treatment of antimicrobial-resistant bacteria [13,14]. Ravishankar and Bai indicated that NPs have distinctive and well characterized physical and chemical properties which can be worked properly for suitable applications [15]. 
Furthermore, their potent antimicrobial action as a result of large surface area to volume ratio has given them an added advantage to face the troubles of antimicrobial resistance. NPs in the range of 2 to $100 \mathrm{~nm}$ are believed to be NPs [14]. Silver nanoparticles (AgNPs) were studied by Rajawat and Qureshi who discovered a promising antimicrobial activity against a wide variety of bacteria and fungi [16]. The highest susceptibility of AgNPs was noticed against Methicillin resistant Staphylococcus aureus (MRSA) while; a moderate antimicrobial activity was observed in different isolates of gram negative pathogens such as Salmonella typhi $[15,17]$. The main causes of using AgNPs as antimicrobial agents are chiefly due to its wide spectrum of activity, low cost and high efficacy rate [15]. Previous researches demonstrated that the antimicrobial effect of AgNPs could be used as valuable bactericidal agents. Due to the current progresses in research on metal NPs, AgNPs have received special attention as a potent antimicrobial agent. When certain particles are extremely small size, nanosize, the number of particles may be increased in the unit area. Dehkordi et al. [18] found that the total surface area of the nanosized AgNPs is larger than that of large-sized silver in identity volume, and then the antimicrobial activity of the AgNPs is more effective than the large-sized silver. Consequently, the syntheses and characterization of small sized particles open the chance of formulation of a new generation of bactericidal agents. Sreekanth et al. [19] noticed that the antimicrobial activity of Gold nanoparticles (AuNPs) was increased due to their larger total surface area per unit volume. Therefore, AuNPs have higher antimicrobial and antifungal activity than large-sized gold [20,21]. Lokina and Narayanan studied the antimicrobial and antifungal activities of AuNPs synthesized from grape extract and they reported that the AuNPs had a promising effect against most the tested fungal and multidrug resistant strains of bacteria [22,23]. The efficacy of the antibacterial activity of AuNPs can be increased by adding antibiotics [15]. Moreover, copper nanoparticles (CuNPs) are observed to have antimicrobial activity against several species of bacteria and fungi [14]. Scanty studies have indicated that CuNPs have antimicrobial activity against bacteria such as E. coli and Staphylococcus species and similar antifungal properties were also reported $[22,24,25]$. Unfortunately, in a parallel way, while scientists develop new, efficient antimicrobial agents, there is no doubt that microbial tolerance to silver also is produced. Consequently, other heavy metals, mainly gold and copper, have been tested to study their various antibacterial effects [26]. Referring to the existing scientific literature, no data have been published in antimicrobial activity and the onset time of action of AgNPs, AuNPs and CuNPs against various bacterial species isolated from diarrheal calf. Therefore, the objectives of the current study were thus to (i) isolate and identify various bacteria isolated from feces of calves suffering from diarrhea, including Gram-negative bacteria such as E. coli, S. typhimurium and Gram-positive bacteria such as $S t$. aureus and (ii) to evaluate the antimicrobial activity and onset time of action of AgNPs, AuNPs and CuNPs against the antibiotic-resistant bacterial isolates.

\section{Materials and Methods}

\section{Nanoparticles}

AgNPs colloidal solution (Cat. No: PL-Ag-S10-5 mg, $10 \mathrm{~nm}$ \& Cat. No: PL-Ag-S20-5 mg, $20 \mathrm{~nm}$ ), AuNPs colloidal solution (Cat. No: PLAu-S10-0.05 mg, $10 \mathrm{~nm} \&$ Cat. No: PL-Au-S20-5mg, $20 \mathrm{~nm}$ ) and CuNPs colloidal solution (Cat. No: PL-Au-S10-0.05 mg, $10 \mathrm{~nm} \&$ Cat. No: PL-Au-S20-5 mg, $20 \mathrm{~nm}$ ) were used in the current study. All NPs were purchased from PlasmaChem GmbH, Rudower Chaussee 29, D-12489 Berlin, Germany.

\section{Sample collection}

Fecal samples from the perineal region of 153 young calves (3- 6 months of age) suffering from diarrhea were collected into sterile plastic tubes and transported to the laboratory in a cool box. Samples were directly placed onto peptone water and incubated overnight at $37^{\circ} \mathrm{C}$ as pre-enrichment. A loopful from each of the peptone water was then cultured onto MacConkey agar (MCA) (Oxoid, UK) and Columbia agar supplemented with $5 \%$ horse blood (bioMérieux). All the culture plates were incubated aerobically and anaerobically at $37^{\circ} \mathrm{C}$ for 24-48 h. To obtain a pure bacterial culture, suspect colonies were carefully picked and subcultures on blood agar and nutrient agar and then incubated for $18-24 \mathrm{~h}$ at $37^{\circ} \mathrm{C}$. A stock culture from each isolate was then stored at $4^{\circ} \mathrm{C}$ for further analysis.

\section{Detection of bacterial fecal pathogens}

Isolation and biochemical reactivity of E. coli, Salmonella spp and St. aureus: The main culture was carried out in Nutrient agar and Nutrient broth media. Subcultures were done in MCA, Blood agar, Staphyloccous agar no. 110, Eosin-Methylene Blue (EMB) agar, Salmonella-Shigella (SS) agar to obtain pure cultures and to study the cultural characteristics of E. coli, Salmonella spp. and St. aureus. The microorganisms were isolated from suspected cases of fecal samples, then stained with Gram's staining techniques according to Merchant and Packer [27]. After culture characterization of E. coli, Salmonella and St. aureus on different culture media as EMB agar, SS agar and Staphylococcus agar No. 110; all isolates were identified by various biochemical tests including Triple sugar iron (TSI) agar slant reaction, Voges-Proskauer (VP), Methyl-Red (MR), Indole and Motility indole urease (MIU) according to the methods described by Merchant and Packer [27].

\section{Molecular diagnosis of $E$. coli, Salmonella spp and $S t$. aureus}

Molecular identification of $E$. coli strains: A total of 36 isolated strains of E. coli were grown in nutrient broth at 37C for 18-24 h. 1.5 $\mathrm{ml}$ of the culture was centrifuged at $5000 \mathrm{rpm}$ for $10 \mathrm{~min}$. The bacterial pellet was lysed by boiling for one minute in $150 \mu$ of Distilled Water (DW) in a water bath. The lysate was centrifuged again as mentioned above and the supernatant containing DNA was used directly as template for PCR. Molecular detection of $E$. coli isolates were carried out by PCR for the presence of Heat-Stable (ST) and Heat-Labile Exotoxin (LT) enterotoxin genes. The primers presented in Table 1 magnify Heat-Stable (STa) and Heat Labile (LT1) enterotoxins, respectively [28]. These oligonucleotide primers were designed by Biomers, Ulm, Germany. PCR technique was carried out in a $25 \mu \mathrm{l}$ reaction volume containing $0.5 \mu \mathrm{M}$ of each primer, PCR master mix with $3 \mathrm{~mm}$ of $\mathrm{MgCl}_{2}$ and $3 \mu \mathrm{l}$ of template DNA. The reaction mixtures were amplified with 25 cycles, each consisting of $30 \mathrm{~s}$ at $94 \mathrm{C}, 60 \mathrm{~s}$ at $45 \mathrm{C}$ and $90 \mathrm{~s}$ at $72 \mathrm{C}$ in a T100 thermal cycler (BioRad, USA) for both genes independently. Amplified PCR products were analyzed by gel electrophoresis in $1.5 \%$ agarose gel containing ethidium bromide [29]. The products were visualized with PhotoDoc-It ${ }^{\mathrm{TM}} 65$ Imaging system (Cambridge, UK). 
Citation: El Behiry A (2014) Diagnostic Aspects and Novel Approach for Treatment of Antibiotic-Resistant Bacteria Isolated from Diarrheal Calves using Silver, Gold and Copper Nanoparticles. J Bacteriol Parasitol 5: 195. doi:10.4172/2155-9597.1000195

Page 3 of 9

\section{Molecular identification of Salmonella spp.}

The bacterial DNA of Salmonella spp. was extracted by diluting the fecal samples 10 fold in phosphate buffered saline. According to the method explained by Chiu and $\mathrm{Ou}, 1 \mathrm{ml}$ of the diluted sample was inoculated into Selenite broth and incubated at $37^{\circ} \mathrm{C}$ for $6 \mathrm{~h}$ without shaking [30]. $1 \mathrm{ml}$ of each culture was centrifuged and then the sediment was washed six times with sterilized water and finally suspended in $1 \mathrm{ml}$ of sterilized water.

\begin{tabular}{|l|l|l|l|}
\hline Isolate & Amplified gene & Forward PCR primer sequence (5"-3") & Reverse PCR primer sequence (5"-3) \\
\hline E. coli & ST & TTTATTTCTGTATTG TCTTT & ATTACAACACAGTTCACAG \\
\hline & LT & AGCAGGTTTCCCACCGGATCACCA & GTGCTCAGATTCTGGGTCT \\
\hline Salmonella sp. & fimA & CCTTTCTCCATCGTCCTGAA & TGGTGTTATCTGCCTGACCA \\
\hline St. aureus & nuc & TCAGCAAATGCATCACAAACAG & CGTAAATGCACTTGCTTCAGG \\
\hline & mecA & GGGATCATAGCGTCATTATTC & AACGATTGTGACACGATAGC \\
\hline & 16S rRNA & GTGCCAGCAGCCGCGGTAA & AGACCCGGGAACGTATTCAC \\
\hline
\end{tabular}

Table 1: PCR primer sequences used for identification of E. coli, Salmonella spp. and St.aureus isolated from feces of calves suffering from diarrhea

Then, the suspension was kept at $95^{\circ} \mathrm{C}$ for $15 \mathrm{~min}$ and after centrifugation at $5000 \mathrm{rpm}$ for $5 \mathrm{~min}, 10 \mathrm{ml}$ or the supernatant was directly used for PCR. PCR amplifications were carried out by a pair of primers specific for the fimA gene encoding for the biosynthesis of fimbriae A of Salmonella spp. As shown in Table 1, the pair of primers amplifies 85-bp fimA gene fragment. The PCR amplification mixture $(25 \mu l)$ which was used for the detection each gene includes $12.5 \mu \mathrm{l}$ of (Green master mix, 2x, which provided by Promega, U.S.A.) include: bacterially derived Taq DNA polymerase; dNTPs which include: 400 $\mu \mathrm{M}$ of each dATP, dGTP, dCTP, dTTP; $3 \mathrm{mM}$ of $\mathrm{MgCl}_{2}$; Yellow and blue dyes as loading dye), $2.5 \mu \mathrm{l}$ of template DNA, $1.25 \mu \mathrm{l}$ of each forwarded and backward primers and $7.5 \mu \mathrm{l}$ of nuclease free water to complete the amplification mixture to $25 \mu$ l. The PCR tubes containing an amplification mixture were transferred to a T100 thermal cycler (BioRad, USA) and started the program for amplification of the fimA gene. After PCR, the profiles of amplification products were detected by gel electrophoresis. Ten microliters of the total reaction mixture was loaded on a $2 \%$ agarose gel and electrophoresed at $100 \mathrm{~V}$ at $70 \mathrm{~mA}$ for 45 to $60 \mathrm{~min}$. The amplified DNA fragments were visualized by PhotoDoc-It ${ }^{\mathrm{TM}} 65$ Imaging system (Cambridge, UK).

\section{Molecular identification of $\boldsymbol{S t}$. aureus strains}

PCR amplifications were done with a pair of primers specific for the nuc gene which encodes of the St. aureus -specific region of the thermonuclease gene St. aureus, mecA, a determinant of methicillin resistant and a genus-specific $16 \mathrm{~S}$ rRNA sequence used as an internal amplification control for staphylococcal DNA. PCR primers specific for St. aureus nuc gene, mecA gene and 16S rRNA gene were designed according to the sequences published by Biomers, Ulm, Germany. The three pairs of primers amplify 255-bp nuc gene fragment, 527-bp mecA gene fragment and 886-bp 16S rRNA gene fragment, respectively. PCR amplification was carried out in $0.5 \mathrm{ml}$ tubes in a final reaction volume of $24 \mu \mathrm{l}$. The PCR master-mix consisted of 22.5 $\mu \mathrm{l}$ ready-mix, $0.5 \mu \mathrm{l}$ purified water, nuc-F $(0.25 \mu \mathrm{l})$, nuc- $\mathrm{R}(0.25 \mu \mathrm{l})$, mec-F $(0.25 \mu \mathrm{l})$, and mec- $\mathrm{R}(0.25 \mu \mathrm{l})$. A DNA sample of $1 \mu \mathrm{l}$ was used as the target in the PCR. The amplification was done with an automated T100 Thermal Cylcer (BioRad, USA).

\section{Antimicrobial resistance of fecal pathogens}

Primarily, all isolates sub-cultured on Mueller-Hinton agar plates and incubated at $37^{\circ} \mathrm{C}$ for 18 to $24 \mathrm{~h}$ aerobically. Then the isolates were suspended in $0.1 \mathrm{ml}$ sodium phosphate solution thus the turbidity was equal to that of a $0.5 \mathrm{McF}$ arland standard and streaked again onto Mueller-Hinton agar plates. MICs were determined by broth microdilution according to Clinical Laboratory Standards Institute standards using a 96 microtiter plate (Sensititre, Trek Diagnostic Systems, Westlake, $\mathrm{OH}$ ) [31]. Salmonella and E. coli isolates were examined using a custom plate developed for Gram-negative bacteria (catalog \# CMV1AGNF); St. aureus isolates were examined utilizing a custom plate developed for Gram positive bacteria (catalog \# CMV2AGPF). CLSI suggestions were followed by testing, quality control organisms, each time antibiotic resistance testing was carried out. The quality control organisms included $E$. coli ATCC 25922, $S$. typhimurium ATCC 14028 and St. aureus ATCC 29213. Briefly, Mueller-Hinton agar plates were streaked with bacterial Cryobank to obtain isolated colonies. After incubation at $37^{\circ} \mathrm{C}$ overnight, select 4 or 5 well-isolated colonies with an inoculating needle or loop, and transfer the growth to a tube of sterile saline of $\mathrm{NaCl}$ and vortex thoroughly. The turbidity of the actively growing broth culture is adjusted by using Sensititre ${ }^{\mathrm{TM}}$ Nephelometer (TREK Diagnostic Systems, East Grinstead, UK) with sterile saline to obtain turbidity optically comparable to that of the $0.5 \mathrm{McF}$ arland standards (ca. $1 \times$ $10^{5}$ colony forming unit (cfu) $/ \mathrm{ml}$ ) and then inoculate $11 \mathrm{ml}$ cation adjusted Mueller-Hinton broth tube with 15-50 $\mu$ l of the adjusted broth culture. Screw the dosing head on the tube and inoculate $50 \mu \mathrm{l}$ in each well of the microtitre plate. The microtitre plates were sealed with a foil and then incubated for $24 \mathrm{~h}$ at $37^{\circ} \mathrm{C}$. Interpretation of all plates was achieved using the Sensititre automatic reader (TREK Diagnostic Systems, East Grinstead, UK).

\section{Efficacy of NPs against antibiotic resistant fecal bacteria}

The current study investigated whether antibiotic resistant $E$. coli, Salmonella spp. and St. aureus strains were susceptible to AgNPs, AuNPs and CuNPs. The MIC determinations of the tested NPs for a total 35 antibiotic-resistant isolates of E. coli (15 isolates), Salmonella spp. (10 isolates) and St. aureus (10 isolates) were carried out using the 
serial dilution technique. The dilutions tested were 0.039 to $160 \mu \mathrm{g} / \mathrm{ml}$ and the MIC was calculated after $24 \mathrm{~h}$ of incubation at $37^{\circ} \mathrm{C}$. The first dilution with no visible growth was considered as the MIC for each isolate. The concentration of the AgNPs, AuNPs and CuNPs capable of stop the observable growth of $50 \%$ of a population of microorganisms is known as $\mathrm{MIC}_{50}$ and the concentration of the AgNPs, AuNPs and CuNPs able to inhibit the observed growth of $90 \%$ of a population of microorganisms is defined as $\mathrm{MIC}_{90}$. Pure colonies were used: E. coli ATCC 25922, S. typhi ATCC 14028 and St. aureus ATCC 25923.

\section{Determination of the initial action of NPs}

To test the beginning action of AgNPs, AuNPs and CuNPs, $0.1 \mathrm{ml}$ of tryptose soya broth (TSB) media containing $3 \times 10^{8} \mathrm{cfu} / \mathrm{ml}$ from each isolate were inoculated into 13 sterile test tubes, each having $20 \mathrm{ml}$ of TSB plus Ag $(10 \mu \mathrm{g} / \mathrm{ml}), \mathrm{Au}(20 \mu \mathrm{g} / \mathrm{ml})$ and $\mathrm{Cu}(40 \mu \mathrm{g} / \mathrm{ml}) \mathrm{NPs}$ (the concentration of NPs used in this trial was the same as $\mathrm{MIC}_{90}$ obtained in the previous test). The media were incubated at $37^{\circ} \mathrm{C}$ for $0,1,5,10$, $15,30,45,60,90,120$, and $180 \mathrm{~min}$ (for tubes no. 1 to 13 ), respectively. Using a sterile swab, samples from these tubes were sub-cultured onto plates containing $8 \mathrm{ml}$ of blood agar and incubated at $37^{\circ} \mathrm{C}$ for three days. The test was repeated two times to obtain correct results.

\section{Results}

\section{Characterization of bacterial fecal pathogens}

Isolation and identification of E. coli, Salmonella spp., and St. aureus were carried out by using morphological, biochemical and genotypic characteristics. A total of 84 bacterial isolates were obtained from the 153 fecal samples. E. coli was considered the most frequent bacterium isolated (36.90\%) followed by Salmonella sp. as the second most prevalent (19.04\%) (Table 2). Further isolates such as Klebsiella spp. (16.66\%), St. aureus (11.90\%), Enterococcus fecalis $(8.33 \%)$ and
Shigella sp. (7.14\%) were isolated respectively. In the current study, all samples were found positive for $E$. coli gives a positive reaction to lactose fermentation on MacConkey agar plate, metallic green sheen colonies on EMB plates and yellowish green colonies on Brilliant Green Agar (BGA). All samples were positive for Salmonella producing negative reaction to lactose fermentation on MacConkey agar plate. Opaque, transparent and pale colonies were produced on SS agar and pale pink color colonies against a pinkish background on the BGA. Additionally, all samples were found positive for St. aureus producing yellowish colonies on tryptose soya agar and hemolysis on blood agar (Table 3). The various isolates of E. coli, Salmonella and $S t$. aureus demonstrated identical results in various biochemical assays including sugar fermentation, Triple Sugar Iron (TSI) slant, Motility Indole Urease (MIU) test, Indole, Methyl Red and Voges-Proskauer Test (MR-VP), citrate utilization tests and Coagulase test. St. aureus produce acid but no gas by fermenting various sugars and gave positive reaction to coagulase, catalase and methyl red tests but negative reaction to Indole and Voges Proskeur test.

\begin{tabular}{|l|l|l|}
\hline Bacterial isolates & Number of isolates & Percentage (\%) of isolates \\
\hline Escherichia coli & 31 & 36.90 \\
\hline Salmonella spp & 16 & 19.04 \\
\hline Klebsiella spp & 14 & 16.66 \\
\hline St. aureus & 10 & 11.90 \\
\hline Enterococcus fecalis & 7 & 8.33 \\
\hline Shigella spp & 6 & 7.14 \\
\hline Total & 84 & 100.00 \\
\hline
\end{tabular}

Table 2: Frequency of bacterial species isolated from calves suffering from diarrhea

\begin{tabular}{|l|l|l|l|}
\hline \multirow{2}{*}{$\begin{array}{l}\text { Culture } \\
\text { media utilized }\end{array}$} & Detection & \multicolumn{2}{l|}{ St. aureus } \\
\cline { 2 - 4 } & E. coli & Salmonella spp. & $\begin{array}{l}\text { Growth of circular, small, smooth, } \\
\text { convex, and golden yellowish colonies }\end{array}$ \\
\hline Nutrient agar & $\begin{array}{l}\text { Smooth, rounded, white to grayish } \\
\text { colony with unusual putrid odor }\end{array}$ & Small, circular and smooth colonies & Demonstrate haemolysis \\
\hline Blood agar & Demonstrate haemolysis & Demonstrate haemolysis & No growth (-) \\
\hline Mac Conkey agar & Rosy pink lactose fermenter colonies. & Colorless, pale, translucent colony. & No growth (-) \\
\hline Salmonella, Shigella (SS) agar & Pink color colony & Translucent colorless smooth colony & Yellow colonies \\
\hline Staphyloccous Agar no. 10 & No growth (-) & No growth (-) & No growth (-) \\
\hline Eosin-Methylene Blue (EMB) agar & $\begin{array}{l}\text { Moist circular colonies with dark centers } \\
\text { yellow, green metallic sheen }\end{array}$ & No growth (-) & \\
\hline
\end{tabular}

Table 3: Identification of isolated microbial pathogens by cultural properties

From a total of 153 samples taken from calves with diarrhea, $31 \mathrm{E}$. coli isolates were obtained. 22 isolates carried the gene for LT alone, five carried the gene for the ST, and the remaining four isolates carried genes for both LT and ST (Figure 1). All Salmonella strains "standard and isolated" (Figure 2) were positive for the amplification of the fimA gene and the specific PCR product " 85 bp fragment" was visualized by agarose gel electrophoresis and ethidium bromide staining. No amplification could be observed with all non Salmonella strains. The St. aureus strains were amplified, while the non St. aureus were not. The PCR product appeared as a single DNA band with a size close to that of the 255-bp (Figure 3). Repeat testing of some of the strains that we examined showed the same results. The sensitivity and specificity of the universal $16 \mathrm{~S}$ rRNA primer set, mecA as well as that of the nuc gene primer set were about $100 \%$. 
Citation: El Behiry A (2014) Diagnostic Aspects and Novel Approach for Treatment of Antibiotic-Resistant Bacteria Isolated from Diarrheal Calves using Silver, Gold and Copper Nanoparticles. J Bacteriol Parasitol 5: 195. doi:10.4172/2155-9597.1000195

Page 5 of 9

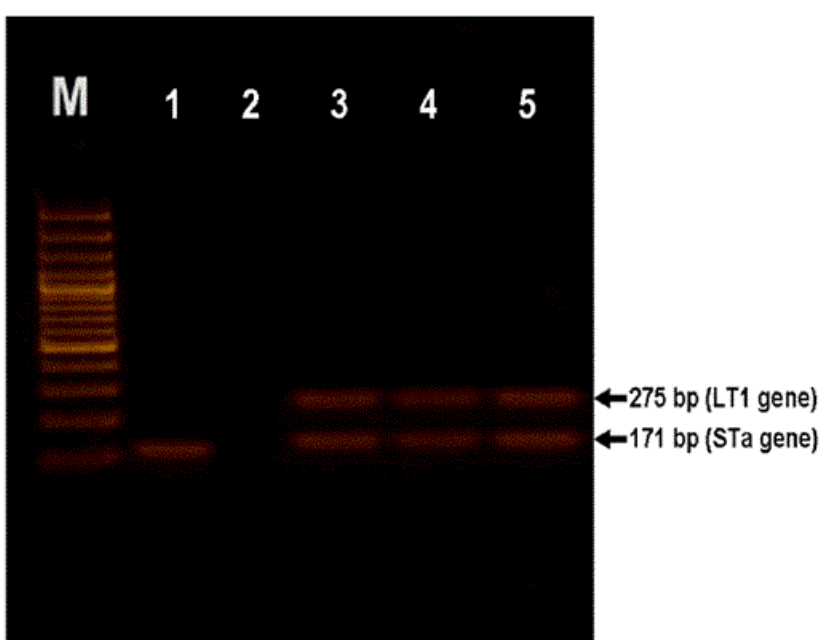

Figure 1: DNA amplification of a $171 \mathrm{bp}$ and bp of E.coli detecting STa and LT1 genes. Lane M: DNA molecular marker (I100 bp ladder), lanel: control positive, lane: control negative, $3,4,5$ positive results as E.coli.

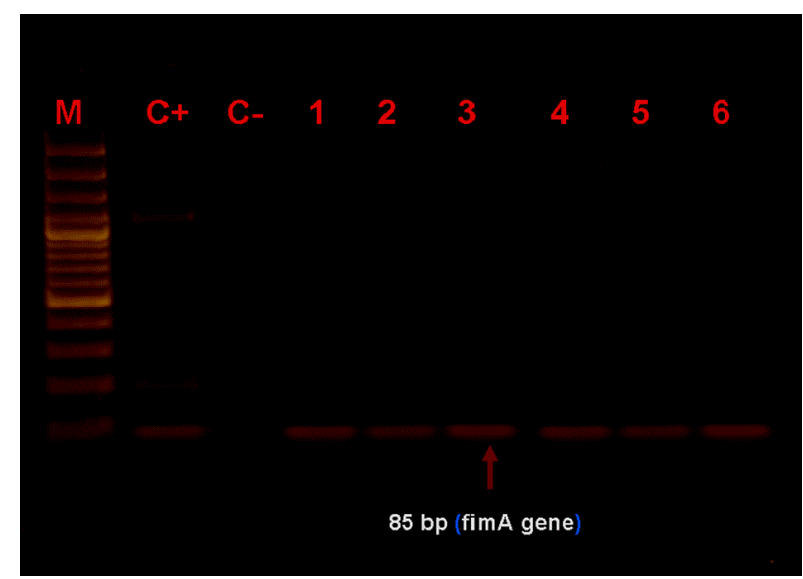

Figure 2: DNA amplification of a 85 bp of Salmonella spp. detecting fimA gene. M: 100 bp marker, $\mathrm{C}+$ : control posive, C-: control negative, $1,2,3,4,5,6$, posive results as salmonella spp.

\section{The antimicrobial effect of AgNPs, AuNPs and CuNPs against bacterial calf diarrhea}

The present study is the first one to evaluate the activity and onset time of action of AgNPs, AuNPs and CuNPs on E. coli, Salmonella and St. aureus strains isolated from the feces of calves suffering from diarrhea. Using the serial dilution method, the MIC range, $\mathrm{MIC}_{50}$ and $\mathrm{MIC}_{90}$ values (MIC that inhibited 50 and $90 \%$ of the isolates tested, respectively) of AgNPs, AuNPs and CuNPs for E. coli, Salmonella and St. aureus field isolates are summarized in Table 4. According to the results, the MIC range values of silver nanoparticles (10 NM) against E. coli, Salmonella and St. aureus strains were $0.625-5 \mu \mathrm{g} / \mathrm{ml}, 1.25-10$ $\mu \mathrm{g} / \mathrm{ml}$ and $0.625-5 \mu \mathrm{g} / \mathrm{ml}$ with $\mathrm{MIC}_{90}$ values of $5 \mu \mathrm{g} / \mathrm{ml}, 10 \mu \mathrm{g} / \mathrm{ml}$ and 5 $\mu \mathrm{g} / \mathrm{ml}$, respectively. While this range value of AgNPs (20 NM) was
$0.312-2.5 \mu \mathrm{g} / \mathrm{ml}, 0.312-2.5 \mu \mathrm{g} / \mathrm{ml}, 0.625-2.5 \mu \mathrm{g} / \mathrm{ml}$ with $\mathrm{MIC}_{90}$ values of 2.5 for the three tested pathogens, respectively.

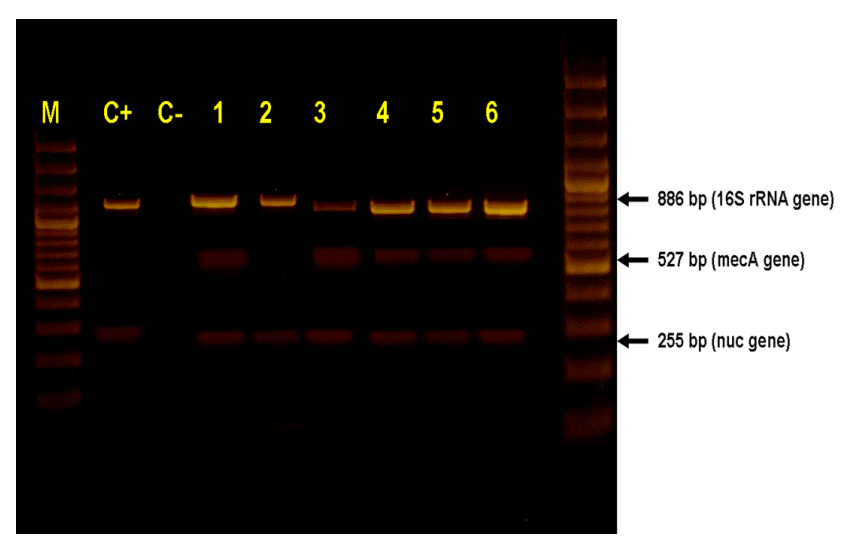

Figure 3: Lane $M$, molecular size marker (100 bp marker); Lane 1, 3, $3,4,5,6$ positive 16S RNA and nuc genes. Lane 2, negative mecA gene. $\mathrm{C}+$ : control positive, $\mathrm{C}$-: control negative

The MIC range values of AuNPs (10 NM) against E. coli, Salmonella and St. aureus strains were $2.5-20 \mu \mathrm{g} / \mathrm{ml}, 5-20 \mu \mathrm{g} / \mathrm{ml}$ and $5-10 \mu \mathrm{g} / \mathrm{ml}$ with $\mathrm{MIC}_{90}$ values of $20 \mu \mathrm{g} / \mathrm{ml}, 20 \mu \mathrm{g} / \mathrm{ml}$ and $10 \mu \mathrm{g} / \mathrm{ml}$, respectively. While these range values for AuNPs (20 NM) were 2.5-10 $\mu \mathrm{g} / \mathrm{ml}, 1.25-5 \mu \mathrm{g} / \mathrm{ml}, 2.5-10 \mu \mathrm{g} / \mathrm{ml}$ with $\mathrm{MIC}_{90}$ values of $10 \mu \mathrm{g} / \mathrm{ml}, 5$ $\mu \mathrm{g} / \mathrm{ml}$ and $10 \mu \mathrm{g} / \mathrm{ml}$ for the three bacteria, respectively. The MIC range values of CuNPs (10 NM) against E. coli, Salmonella and St. aureus strains were $5-20 \mu \mathrm{g} / \mathrm{ml}, 2.5-20 \mu \mathrm{g} / \mathrm{ml}$ and $2.5-20 \mu \mathrm{g} / \mathrm{ml}$ with $\mathrm{MIC}_{90}$ values of $20 \mu \mathrm{g} / \mathrm{ml}$ for the three types of bacteria, respectively. While the MIC range values of CuNPs $20 \mathrm{NM}$ was $2.5-10 \mu \mathrm{g} / \mathrm{ml}$ with $\mathrm{MIC}_{90}$ values of $10 \mu \mathrm{g} / \mathrm{ml}$ for all tested pathogens. From the previous results, all isolates were susceptible to AgNPs, AuNPs and CuNPs.

In addition, the results of the current investigation performed for determining of the onset time of the antibacterial action of AgNPs, AuNPs and CuNPs are demonstrated in Table 4. The range of the onset time of action was 1-5 min, 15-30 min and 5-30 min for AgNPs, AuNPs and CuNPs, respectively. Therefore, the result of the current investigation demonstrated that nanoparticles of silver with a concentration of $5-10 \mu \mathrm{g} / \mathrm{ml}$ after 1-5 min are able to kill $E$. coli, Salmonella and St. aureus isolates. While AuNPs with a concentration of $40-80 \mu \mathrm{g} / \mathrm{ml}$ ) after $15-30 \mathrm{~min}$ and CuNPs with a concentration of $2.5-20 \mu \mathrm{g} / \mathrm{ml}$ after 5-30 min are able to kill nearly all isolates of testing bacteria.

\section{NPs and antibiotics resistance in isolated bacteria}

A total of 31 isolates of E. coli, 16 Salmonella spp. and 10 St. aureus demonstrated resistance to at least one of the tested antimicrobials. $74 \%-87 \%$ of E. coli strains, $75 \%$ of Salmonella spp. and $80 \%$ of St. aureus were resistant to no less than three antimicrobial agents such as ampicillin, tetracycline and sulfisoxanole. Additionally, 50\%-70\% of $E$. coli strains, $60 \%$ of Salmonella spp. and $70 \%$ of St. aureus were resistant to amoxicillin and chloramphenicol. However, nearly $20 \%$ of all isolates were resistant to ceftiofur, naildixic acid. These results suggested that the antimicrobial resistance of the E. coli might be derived from the excessive use of antimicrobials of their hosts. In contrast, all isolates demonstrated no degree of resistance when treated with different concentrations of AgNPs, AuNPs and CuNPs (Table 5). 
Citation: El Behiry A (2014) Diagnostic Aspects and Novel Approach for Treatment of Antibiotic-Resistant Bacteria Isolated from Diarrheal Calves using Silver, Gold and Copper Nanoparticles. J Bacteriol Parasitol 5: 195. doi:10.4172/2155-9597.1000195

Page 6 of 9

\begin{tabular}{|l|l|l|l|l|l|l|l|l|l|l|l|l|}
\hline & $\begin{array}{l}\text { Dilution range } \\
(\mu \mathrm{g} / \mathrm{ml})\end{array}$ & \multicolumn{2}{l|}{ Mean MIC } & \multicolumn{2}{l|}{$\begin{array}{l}\text { Average } \\
\text { start time } \\
\text { (min) }\end{array}$} \\
\hline Ws & All isolates & A & B & C & A & B & C & A & B & C & \\
\hline Silver $10 \mathrm{~nm}$ & $0.039-160$ & $0.625-5$ & L25-10 & $0.625-5$ & 2.5 & 5 & 1.25 & 5 & 10 & 5 & 5 \\
\hline Silver $20 \mathrm{~nm}$ & $0.039-160$ & $0.312-$ & $0.31-$ & $0.625-$ & 1.25 & 1.25 & 1.25 & 2.5 & tr) & 2.5 & 1 \\
\hline Gold $10 \mathrm{~nm}$ & $0.039-160$ & 2.5 & 2.5 & 2.5 & 5 & 10 & 5 & 20 & 20 & 10 & 30 \\
\hline Gold $20 \mathrm{~nm}$ & $0.039-160$ & $2.5-20$ & $5-20$ & $5-10$ & 5 & 5 & 5 & 10 & if") & 10 & 15 \\
\hline Copper $10 \mathrm{~nm}$ & $0.039-160$ & $2.5-10$ & $1.25-5$ & $2.5-10$ & 10 & 10 & 10 & 20 & 20 & 20 & 15 \\
\hline Copper $20 \mathrm{~nm}$ & $0.039-160$ & $5-20$ & $2.5-20$ & $2.5-20$ & 5 & 5 & 2.5 & 10 & 10 & 10 & 5 \\
\hline
\end{tabular}

Table 4: Determination of MIC and onset time of action of the AgNPs, AuNPs and CuNPs against E. coli, S. typhyimurium and St. aureus isolated from feces of calves suffering from diarrhea. $\mathrm{A}=$ E. coli, $\mathrm{B}=$ Salmonella, $\mathrm{C}=$ St. aureus.

\begin{tabular}{|l|l|l|l|}
\hline \multirow{2}{*}{ Antimicrobial agent } & \multicolumn{3}{|l|}{ Percentage (\%) of resistant strains } \\
\cline { 2 - 4 } & A (31 strains) & B (16 strains) & C (10 strains) \\
\hline Nanoparticles & & & \\
\hline Silver 10 $\mathrm{nm}$ & 0 & 0 & 0 \\
\hline Silver 20 $\mathrm{nm}$ & 0 & 0 & 0 \\
\hline Gold 10 $\mathrm{nm}$ & 0 & 0 & 0 \\
\hline Gold 20 nm & 0 & 0 & 0 \\
\hline Copper 10 nm & 0 & 0 & 0 \\
\hline Copper 20 $\mathrm{nm}$ & 0 & 0 & 0 \\
\hline Antibiotics & & & \\
\hline Amikacin & 41.93 & 43.75 & 30 \\
\hline Ampicillin & 74.19 & 75 & 80 \\
\hline Amoxicillin & 67.74 & 62.5 & 70 \\
\hline Ceftriaxone & 45.16 & 43.75 & 50 \\
\hline Chloramphenicol & 70.96 & 56.25 & 70 \\
\hline Ciprofloxacin & 32.25 & 31.25 & 30 \\
\hline Cefoxitin & 41.93 & 37.5 & 40 \\
\hline Gentamycin & 58 & 56.25 & 40 \\
\hline Kanamycin & 19.35 & 18.75 & 20 \\
\hline Naildixic acid & 22.58 & 25 & 20 \\
\hline Sulfisoxanole & 87 & 75 & 80 \\
\hline Streptomycin & 41.93 & 43.75 & 30 \\
\hline Tetracycline & 80.64 & 75 & 80 \\
\hline & & & 0 \\
\hline
\end{tabular}

\begin{tabular}{|l|l|l|l|}
\hline Ceftiofur & 22.58 & 12.5 & 20 \\
\hline
\end{tabular}

Table 5: Comparison between the resistance of NPs and antibiotics against E. coli, $S$. typhimurium and $S$ t. aureus strains isolated from calves suffered from diarrhea.

\section{Discussion}

\section{Identification of bacterial fecal pathogens}

In the current investigation, three various types of bacteria (E. coli, Salmonella and St. aureus) were isolated from a total of 153 fecal specimens collected from form pre-weaned calves suffering from diarrhea. 31 samples were identified as $E$. coli which appeared as rosy pink lactose fermenter colonies on MCA plate, moist circular colonies with dark yellow centers, green metallic sheen on EMB plates and yellowish green colonies on the BGA. Sixteen samples were identified phenotypically Salmonella spp. because the organism on MCA plate gave colorless, pale, translucent colony with negative reaction to lactose fermentation, translucent colorless smooth colonies on S-S agar and produce pink color colonies background on the BGA. Ten samples were found positive for St. aureus producing yellow pigmented golden colonies on Staphylococcus agar no. 110 and hemolysis on Blood agar. Dissimilarities in the colony shape appeared by the isolates may be as a result of losing or obtaining some properties by the transfer of host or choice of host tissue as noticed by Abdullah et al. [5].

Various biochemical tests, including Indole, Voges-Poskauer, Methyl-red, Citrate, TSI, MIU and Coagulase were used to distinguish between different isolates of bacteria in this study. E. coli gave positive reactions to Indole and Methyl-red tests, but negative to VogesPoskauer, Citrate and Coagulase tests. St. aureus gave positive reactions to Coagulase and Methyl red tests, however negative reaction to Indole, Voges Proskeur, Citrate and MIU tests was reported. Moreover, Salmonella spp. gave positive results to Methyl-red and MIU tests while negative to the other tests. To date, the real reasons for which the appearance of an identical result in biochemical reactions of the three groups of recognized isolates were not obvious. There is no doubt that nearly all bacterial isolates in the current investigation have 
several common genetic materials which might be responsible for the appearance of similar type of biochemical reaction as reported by Pandey et al. [32] and Honda et al. [33].

All bacteriological and chemically reactive positive fecal samples were also positive with PCR and the specific PCR product for $E$. coli (171 bp fragment of ST gene and $132 \mathrm{bp}$ for LT gene), Salmonella (85 bp fragment) and St. aureus (255 bp fragment) could be demonstrated. Also the results indicated that the PCR amplification of the ST and LT enterotoxin genes of E. coli, fimA gene sequence of $S$. typhimurium and nuc gene sequence could be used as a target sequence for fast and susceptible technique for direct detection of E. coli, Salmonella and St. aureus in the fecal samples of diarrheic calves [34].

\section{Antibiotic resistance and antimicrobial effect of various NPs}

The present study is the first one to evaluate the effect of AgNPs, AuNPs and CuNPs on E. coli, Salmonella and St. aureus isolated from feces of calves suffering from diarrhea. Therefore, the antimicrobial sensitivity test of three various types of bacterial isolates to 14 different antimicrobial agents were studied. The sensitivity investigation demonstrated that the majority of the E. coli, Salmonella spp. and St. aureus were tolerant to ampicillin, tetracycline, sulfisoxanole, amoxicillin and chloramphenicol. Similar results were obtained by Abdullah et al. [5], Ahmed et al. [35], Genovese et al. [36] and Nazir who stated that calf isolates were resistant to ampicillin, amoxicillin, erythromycin and gentamicin [37]. These findings were somewhat different with the results of Panower et al. [38] and Joon \& Kaura who stated that most of the microorganisms isolated from calves suffering from diarrhea were highly susceptible to chloramphenicol and tetracycline and moderately sensitive to ampicillin and amoxicillin [39]. The variation in the susceptibility of antimicrobial agents against the fecal isolates may be due to the outcome of selection and also the random apply of antibiotic in various disease stages to different animal species.

The appearance of multidrug-resistant bacteria is documented as an important problem for public health worldwide. Killing of antibioticresistant microorganisms requires numerous expensive antimicrobial agents that may possibly have harmful effects. Consequently, treatment is expensive and needs prolonged time. A novel approach can be offered by nanoparticles to deal with multidrug-resistant bacteria [7]. Numerous NPs especially AgNPs have appeared as promising antimicrobial agents in the medical field [40]. NPs are considered alternative antimicrobial agents against antibiotic-resistant bacteria. In the current study, AgNPs, AuNPs and CuNPs illustrated astounding antimicrobial action against E. coli, S. typhi and St. aureus. The bacteria, which are tolerant to antimicrobial agents, established susceptibility to AgNPs, AuNPs and CuNPs $[26,41,42]$. As can be seen from the current results, the mean MIC values of AgNPs, AuNPs and CuNPs (10 and $20 \mathrm{~nm}$ ) against E. coli, S. typhimurium and St. aureus isolates were ranged from $0.62-10 \mu \mathrm{g} / \mathrm{ml}$.

Similar findings have been recorded by other researchers who demonstrated that AgNPs have antimicrobial effects [18]. Lee et al. [11] revealed that AgNPs in colloidal solution at a concentration of 5 ppm have admirable antimicrobial effect against $S$ t. aureus and Klebsiella pneumonia. Furthermore, Cho et al. [43] reported that the AgNPs with $5 \mathrm{ppm}$ have the ability to kill different isolates of $S t$. aureus. Dehkordi et al. [44] also found that the AgNPs have an excellent effect against Escherichia coli. Lima et al. [26] found that AuNPs in colloidal solution have an excellent biocide against to remove E. coli and S. typhi at short contact times. Furthermore, The antibacterial as well as antifungal activity of the CuNPs were studied by Chatterjee et al. [42] using numerous types of bacteria, including methicillin-resistant St. aureus, Bacillus subtilis, Pseudomonas aeruginosa, Salmonella choleraesuis, and Candida albicans. They found that CuNPs have a promising effect when used at a concentration of $2 \mathrm{~nm}$ within short time. Therefore, NPs with antibacterial properties represent an alternative approach to antimicrobial agents. Their complex mechanism of action influences various bacterial structures and gives them advantages compared to antibiotics with more specific mechanism of action. Targets of NPs are outer and inner bacterial structures (cell wall, plasma membrane, proteins, and DNA).

The antimicrobial action of AgNPs is still not clear. Nevertheless, AgNPs have the capability to attach to the cell wall of the bacterial cell and consequently pierce it, hence causing different structural alterations in the cytoplasmic membrane like the permeability of the plasma membrane and hence the death of the bacterial cell. In addition, attachment of AgNPs to the cell wall of the bacterial cell, will lead to the formation of 'pits' on the cell surface, and there is an accumulation of the nanoparticles on the cell surface $[45,46]$. The formation of free radicals by the AgNPs may be believed to be another cause of the cells die. The exact bactericidal mechanism of CuNPs is still also not clear. CuNPs have a high antimicrobial activity against different types of bacteria. This may be due to a larger quantity of amines and carboxyl groups on the cell surface of bacteria and greater affinity to copper towards these groups. Moreover, releasing of copper ions may interact with DNA molecules and intercalate with nucleic acid strands. Copper ions also inside the microbial cells may disrupt biochemical processes $[15,47]$. AuNPs exert their antimicrobial action mostly by two methods: the first one is to modify membrane potential and inhibit adenosine triphosphate (ATP) synthesis activities to diminish the level of ATP in the cell, leading to a general decline in metabolism; the other is to inhibit the subunit of the ribosome for tRNA binding, indicating a collapse of biological process [48].

The results of the present study demonstrated that the NPs possess antimicrobial properties against various bacterial pathogens. Several investigations have suggested the possible mechanisms involving the interaction of NPs with the biological macromolecules. It is believed that microorganisms carry a negative charge while nanoparticles carry a positive charge. This creates an "electromagnetic" attraction between bacteria and treated surface. Once the contact is made, the microbe is oxidized and dead instantly. In general, it is believed that NPs release ions, which react with the thiol groups (-SH) of the proteins present on the bacterial cell surface [45]. Such proteins protrude through the bacterial cell membrane, allowing the transport of nutrients through the cell wall. NPs inactivate the proteins, decreasing the membrane permeability and eventually causing the cellular death.

Key factors in the interaction of NPs with living tissues include size (NPs with a few nanometres may reach well inside biomolecules), dose, the ability of NPs to distribute within the body, in addition to their solubility. Some NPs dissolve without difficulty and their effects on living organisms are the same as the effects of the chemical they are made of. Nevertheless, other NPs do not degrade or dissolve readily. As an alternative, they may accumulate in biological systems and persist for a long time, which makes such NPs of particular concern. It is suggested that higher concentrations of NPs especially AgNPs are toxic and can cause a variety of health problems [49,50]. Therefore, care has to be taken to use this marvel well and in a good, effective, and efficient way, understanding its limitations and taking significant 
care that it does not cause any harm to an individual or the environment. It can be thought that if used correctly, NPs can be a good friend, but if used haphazardly, they can become a strong enemy [50].

\section{Conclusions}

Based on the results obtained in this study and from literature review, it can be concluded that accurate diagnosis of bacterial calf diarrhea with bacteriological, biochemical and molecular methods is important to develop the best treatment. In addition, a promising effect of silver, gold and copper nanoparticles was recorded in vitro against antibiotic-resistant E. coli, S. typhimurium and St. aureus isolated from feces of calves suffering from diarrhea. However, nanoproducts' safety is a worldwide concern, and continues studies must be conducted in order to better comprehend the nano interactions with organisms and environment.

\section{Acknowledgment}

This work was supported by College of Public Health and Health Informatics, Qassim University, Kingdom of Saudi Arabia. My deepest thanks go to Dr. Amin Asfour, Pirbright institute, Ash Road, Pirbright,- ${ }^{*}$ Woking, Surrey, GU24 0NF, UK for critical reading of this manuscript.

\section{References}

1. Pereira RV, Santos TM, Bicalho ML, Caixeta LS, Machado VS, et al. (2011) Antimicrobial resistance and prevalence of virulence factor genes in fecal Escherichia coli of Holstein calves fed milk with and without antimicrobials. J Dairy Sci 94: 4556-4565.

2. de Verdier K, Nyman A, Greko C, Bengtsson B (2012) Antimicrobial resistance and virulence factors in Escherichia coli from Swedish dairy calves. Acta Vet Scand 54: 2.

3. Wu G, Mafura M, Carter B, Lynch K, Anjum MF, et al. (2010) Genes associated with Escherichia coli isolates from calves with diarrhoea and/or septicaemia. Vet Rec 166: 691-692.

4. Hemashenpagam N, Kiruthiga B, Selvaraj T, Panneerselvam A (2009) Isolation, Identification and Characterization of Bacterial pathogens causing Calf Diarrhea with special reference to Escherichia coli. The Internet Journal of Microbiology 7(2).

5. Abdullah M, Akter MR, Lutful Kabir SM, Abu Sayed Khan, M, Abdul Aziz MS (2013) Characterization of Bacterial Pathogens Isolated from Calf Diarrhea in Panchagarh District of Bangladesh. JAgric Food Tech 3: 8-13.

6. Cho YI, Kim WI, Liu S, Kinyon JM, Yoon KJ (2010) Development of a panel of multiplex real-time polymerase chain reaction assays for simultaneous detection of major agents causing calf diarrhea in feces. J Vet Diagn Invest 22: 509-517.

7. Hajipour MJ, Fromm KM, Ashkarran AA, de Aberasturi DJ, de Larramendi IR, et al.(2013) Antibacterial properties of Nanoparticles. Trends in Biotechnology 31: 61-62.

8. Izzo M, Mohler V, House J (2011) Antimicrobial susceptibility of Salmonella isolates recovered from calves with diarrhoea in Australia. Aust Vet J 89: 402-408.

9. Raffi M, Mehrwan S, Bhatti TM, Akhter JI, Hameed A, et al.(2010) Investigations into the antibacterial behavior of copper nanoparticles against Escherichia coli. Annals of Microbiology 60: 75-80.

10. El Zowalaty ME (2012) Alarming trend of antibiotic resistance in Pseudomonas aeruginosa isolates. Journal of Pure and Applied Microbiology 6: 175-183.

11. Lee CR, Cho IH, Jeong BC, Lee SH (2013) Strategies to minimize antibiotic resistance. Int J Environ Res Public Health 10: 4274-4305.
12. Huh AJ, Kwon YJ (2011) "Nanoantibiotics": a new paradigm for treating infectious diseases using nanomaterials in the antibiotics resistant era. J Control Release 156: 128-145.

13. Janardhanan R, Karuppaiah M, Hebalkar N, Rao TN (2009) Synthesis and surface chemistry of nano silver particles. Polyhedron 28: 2522-2530.

14. Usman MS, El Zowalaty ME, Shameli K, Zainuddin N, Salama M, et al. (2013) Synthesis, characterization, and antimicrobial properties of copper nanoparticles. Int J Nanomedicine 8: 4467-4479.

15. Ravishankar RV, Bai JA (2011) Nanoparticles and their potential application as antimicrobials. Science against microbial pathogens: communicating current research and technological advances A. MéndezVilas (Edn).

16. Rajawat S, Qureshi MS (2012) Comparative Study on Bactericidal Effect of AgNPs, Synthesized Using Green Technology, in Combination with Antibiotics on Salmonella Typhi. J of Biomaterials and Nanobiotechnology 3: 480-485.

17. Nanda A, Saravanan M (2009) Biosynthesis of silver nanoparticles from Staphylococcus aureus and its antimicrobial activity against MRSA and MRSE. Nanomedicine 5: 452-456.

18. Dehkordi SH, Hosseinpour F, Kahrizangi AE (2011) An in vitro evaluation of the antibacterial effect of AgNPs on Staphylococcus aureus isolated from bovine subclinical mastitis. African Journal of Biotechnology 10: 10795-10797.

19. Sreekanth TVM, Nagajyothi PC, Lee K (2012) Biosynthesis of Gold Nanoparticles and Their Antimicrobial Activity and Cytotoxicity. Advanced Science Letters 6: 63-69.

20. Fayaz AM, Balaji K, Girilal M, Yadav R, Kalaichelvan PT, et al. (2010) Biogenic synthesis of silver nanoparticles and their synergistic effect with antibiotics: a study against gram-positive and gram-negative bacteria. Nanomedicine 6: 103-109.

21. Mihai S, Malaisteanu M (2013) Size-dependent Antibacterial of Gold Colloids. Rev Chim Bucharest 64: 105:107.

22. Lokina S, Narayanan V (2013) Antimicrobial and Anticancer Activity of Gold Nanoparticles Synthesized from Grapes Fruit Extract. Chem Sci Trans 2: 105-110.

23. Ruparelia JP, Chatterjee AK, Duttagupta SP, Mukherji S (2008) Strain specificity in antimicrobial activity of silver and copper nanoparticles. Acta Biomater 4: 707-716.

24. Ren G, Hu D, Cheng EW, Vargas-Reus MA, Reip P, et al. (2009) Characterisation of copper oxide nanoparticles for antimicrobial applications. Int J Antimicrob Agents 33: 587-590.

25. Wei Y, Chen S, Kowalczyk B, Huda S, Gray TP, Grzybowski BA (2010) Synthesis of stable, low-dispersity copper nanoparticles and nanorods and their antifungal and catalytic properties. J Phys Chem C 114: 15612-1516.

26. Lima E, Guerra R, Lara V, Guzmán A (2013) Gold nanoparticles as efficient antimicrobial agents for Escherichia coli and Salmonella typhi. Chem Cent J 7: 11.

27. Merchant IA, Packer RA (1967) Veterinary Bacteriology and Virology. (7th Edn) Ames, Iowa, Iowa State University Press 752p.

28. Nishikawa Y, Zhou Z, Hase A, Ogasawara J, Kitase T, Abe N, Nakamura H, Wada T, Ishii E, Haruki K (2002) Diarrheagenic Escherichia coli isolated from stools of sporadic cases of diarrheal illness in Osaka City, Japan between 1997 and 2000: Prevalence of Entero-aggregative E. coli Heat-Stable Enterotoxin 1 Gene-Possessing E.coli. Jpn J Infect Dis 55: 183-190.

29. Sambrook J, Russel DW (2001) Molecular cloning: A laboratory manual (3rd Ed.). Cold Spring Harbor, NY, USA: Cold Spring Harbor Press.

30. Chiu CH, Ou JT (1996) Rapid identification of Salmonella serovars in feces by specific detection of virulence genes, invA and spvC, by an enrichment broth culture-multiplex PCR combination assay. J Clin Microbiol 34: 2619- 2622.

31. CLSI (Clinical Laboratory Standard Institute) (2008) Performance standards for antimicrobial disk and dilution susceptibility tests for 
Citation: El Behiry A (2014) Diagnostic Aspects and Novel Approach for Treatment of Antibiotic-Resistant Bacteria Isolated from Diarrheal Calves using Silver, Gold and Copper Nanoparticles. J Bacteriol Parasitol 5: 195. doi:10.4172/2155-9597.1000195

Page 9 of 9

bacteria collected from animals; Approved standard. (3rd Edn)Wayne, PA.

32. Pandey PN, Thaphyal DC, Sharma SN (1979) Enterotoxigenicity of some Escherichia coli isolates. Indian J Anim Research 13: 1-4.

33. Honda T, Arita M, Takeda Y, Miwatani T (1982) Further evaluation of the Biken test (modified Elek test) for detection of enterotoxigenic Escherichia coli producing heat-labile enterotoxin and application of the test to sampling of heat-stable enterotoxin. J Clin Microbiol 16: 60-62.

34. Moussa IM, Ashgan MH, Mohamed MS, Mohamed KHF, Al-Doss AA (2010) Rapid detection of Salmonella species in newborn calves by polymerase chain reaction. International Journal of Genetics and Molecular Biology 2: 62-66.

35. Ahmad R, Amin M, Kazmi SE (1986) Studied on the bacterial causes of calf mortality. Pak Vet J 6: 116-118.

36. Edrington TS, Hume ME, Looper ML, Schultz CL, Fitzgerald AC, et al. (2004) Variation in the faecal shedding of Salmonella and E. coli O157:H7 in lactating dairy cattle and examination of Salmonella genotypes using pulsed-field gel electrophoresis. Lett Appl Microbiol 38: 366-372.

37. Nazir KH (2007) Plasmid profiles and antibiogram pattern of Escherichia coli isolates of calves feces and diarrhegenic stool of infants. Journal of Bangladesh Society of Agricultural Science and Technology 4(1\&2): 149-152.

38. Guerra B, Junker E, Schroeter A, Helmuth R, Guth BE, et al. (2006) Phenotypic and genotypic characterization of antimicrobial resistance in Escherichia coli O111 isolates. J Antimicrob Chemother 57: 1210-1214.

39. Joon DS, Kaura YK (1993) Isolation and characterization of same of the Enterobacteria from diarrhoeic and non-diarrhoeic calves. Indian J Anim Sci 63: 373-383.

40. Durán N, Marcato PD, De Souza GIH, Alves OL, Esposito E (2007) The antibacterial effect of silver nanoparticles produced by a fungal process of textile fabrics and their effluent treatment. J Biomed Nanotechnol 3: 203-208.
41. Dar MA, Ingle A, Rai M (2013) Enhanced antimicrobial activity of silver nanoparticles synthesized by Cryphonectria sp. evaluated singly and in combination with antibiotics. Nanomedicine 9: 105-110.

42. Chatterjee AK, Chakraborty R, Basu T (2014) Mechanism of antibacterial activity of copper nanoparticles. Nanotechnology 25: 135101.

43. Cho M, Chung H, Choi W, Yoon J (2005) Different inactivation behaviors of MS-2 phage and Escherichia coli in TiO2 photocatalytic disinfection. Appl Environ Microbiol 71: 270-275.

44. Dehkordi SH, Shadnoush F, Arabi M, Safar B (2013) Evaluation of the cytotoxicity and protein expression alteration induced by nanoparticles of silver in the rat sperm and testis. Journal of Shahrekord University of Medical Sciences 15 (4): 26-34.

45. Sondi I, Salopek-Sondi B (2004) Silver nanoparticles as antimicrobial agent: a case study on E. coli as a model for Gram-negative bacteria. J Colloid Interface Sci 275: 177-182.

46. Prabhu S, Poulose EK (2012) REVIEW Open Access Silver nanoparticles: mechanism of antimicrobial action, synthesis, medical applications, and toxicity effects. International Nano Letters 2: 32-41.

47. Ruparelia JP, Chatterjee AK, Duttagupta SP, Mukherji S (2008) Strain specificity in antimicrobial activity of silver and copper nanoparticles. Acta Biomater 4: 707-716.

48. Cui Y, Zhao Y, Tian Y, Zhang W, Lü X, et al. (2012) The molecular mechanism of action of bactericidal gold nanoparticles on Escherichia coli. Biomaterials 33: 2327-2333.

49. Panyala NR, Pena-Mendez EM, Havel J (2008) Silver or silver nanoparticles: a hazardous threat to the environment and human health? J Appl Biomed 6: 117-129.

50. Prabhu S, Poulose EK (2012) Silver nanoparticles: mechanism of antimicrobial action, synthesis, medical applications, and toxicity effects. International Nano Letters 2: 32-41. 